\title{
Incremental innovation: A case study analysis
}

Received: 27th June, 2002

\section{Roger Palmer MBA PhD DipM MCIM ARAgS}

is a Lecturer in Marketing at the Cranfield School of Management. He has substantial practical, industrial experience gained across industry sectors, including as marketing director of a large manufacturing company and CEO/General Manager of the UK/Ireland subsidiary of an American multinational. His teaching and research is largely in the area of business-to-business marketing with particular interests in technology and product development, relationship and value management, and marketing strategy, implementation and practice. He is a leading member of an international research team investigating contemporary marketing practice. He regularly works with national and international companies and consults and teaches around the world. He most recently held a visiting appointment at the University of Auckland. He is a director of a number of companies and has a range of outside business interests.

\section{Richard Brookes}

is Associate Professor and Deputy Head of the Department of Marketing at the University of Auckland, New Zealand. Prior to becoming an academic, he worked in marketing and market research positions in New Zealand and in the UK. His specialty subjects are marketing management and strategy. He teaches mainly on the School's executive programmes and has received a University of Auckland Distinguished Teaching Award. In Addition to working on the Contemporary Marketing Practices (CMP) programme, he researches consumer behaviour issues with restpect to new car buying behaviour. In that context, he is closely involved with ESOMAR, the European Society for Opinion and Market Research. He has published his work in leading international journals (eg Journal of Business Research, Psychology and Marketing and Journal of Marketing Management) as well as book chapters, books and refereed conference proceedings. His Consulting activities include both private and public sector organisations, and he is a Member of the Board of Trustees of the Performing Arts School of New Zealand.

Roger Palmer Cranfield School of Management, Cranfield, Bedford MK43 OAL, UK.

Tel: +44 (0)1234 751122;

Fax: +44 (0)1234 751806 ; e-mail:

r.a.palmer@cranfield.ac.uk
Abstract By its nature innovation suggests that unknown and potentially high risk is incurred. The perils of innovation have been well established, ${ }^{1}$ yet the pressures to innovate and seek new solutions to business problems do not diminish.

Within the knowledge economy there has been a large amount of conceptual work to develop, for example, sophisticated models of customer relationship management. As with other managerially orientated initiatives such as business process re-engineering and total quality management, however, the process of adoption and subsequent business benefits are not consistently apparent to managers. The application of new management thinking and the adoption of innovative techniques are subject to significant risk of failure, with consequent effects on a business already under pressure to improve performance.

This paper considers a traditional, family-orientated firm that has prospered for many years. Business pressures are forcing the company to consider ways in which profitability can be maintained and improved. The actions of the company are considered against two conceptual frameworks. First, the empirically-derived understanding of marketing practice developed by the Contemporary Marketing Practice group, ${ }^{2,3}$ secondly the conceptual approach to the development of database management practice proposed by Shaw and Stone. ${ }^{4}$

The innovation involved the introduction of a database marketing activity within the organisation. The case study demonstrates how the company develops incrementally from a traditional transactional approach to marketing, and adopts database marketing as a means to improve performance. This effectively represents a product being 
developed and internally sold by the marketing department of the organisation to the rest of the company. The success of this process is considered against criteria for product development proposed by Poolton and Barclay. ${ }^{5}$

The paper concludes by noting that adopting an incremental approach can reduce the risks associated with innovation. This is consistent with the frameworks discussed. This may, however, lead to suboptimisation of the potential returns, but may still be consistent with the objectives of the management team.

\section{INTRODUCTION}

Ever-increasing competitive pressures, narrowing margins, availability of new technology and development of marketing techniques mean that marketing managers have ever more complex decisions to make if success is to be achieved and sustained. A report published in 2002 highlights the challenges and complexities of the manager's task, particularly with respect to the utilisation of new technology. ${ }^{6}$ It is apparent that with respect to new technology the rhetoric of advertising campaigns, persuasive conference presentations and journal articles may create a gap distinct from the realities of marketing management.

This paper reports how a business-to-business company recognised the opportunity to develop its market position by utilising a database marketing approach. The conceptual framework of Shaw and Stone ${ }^{7}$ suggests an increasing level of sophistication as the utilisation of information technology increases. The work of the Contemporary Marketing Practice (CMP) group proposes that information technology (IT) tools underpin various marketing practices and act to span the boundary and enable the implementation of alternative marketing practices.

This paper discusses the transition from one style of marketing to another. The process can be considered against the barriers to implementation discussed by Desai, Wright and Fletcher. ${ }^{8}$ The management team of the company concerned treated their adoption of database marketing as an experiment. Full details of the progress of the campaign were recorded and this was then used as an internal sales tool to 'sell' the concept of IT-enabled marketing within the organisation. In effect, the marketing team were 'selling' the database marketing 'product' to the board of directors. The success of this approach is considered against the criteria for innovation and new product introduction discussed by Poolton and Barclay. ${ }^{9}$

A detailed, single case study approach is justified in order to give rich understanding within the context of business-to-business marketing. ${ }^{10}$ The study is exploratory as the barriers to implementation were initially developed within the context of the financial services, retail and travel industries. ${ }^{11}$

This paper is therefore positioned within a conceptual framework and supported by empirical findings concerning the types of marketing practice (Figure 1). The implementation and transition process is considered against barriers to successful implementation and concludes by considering the overall success of the project against the criteria for new product development. This is an exploratory, single case study that extends the discussion within the context of a business-to-business company.

Shaw and Stone ${ }^{17}$ propose four phases of development as IT becomes 


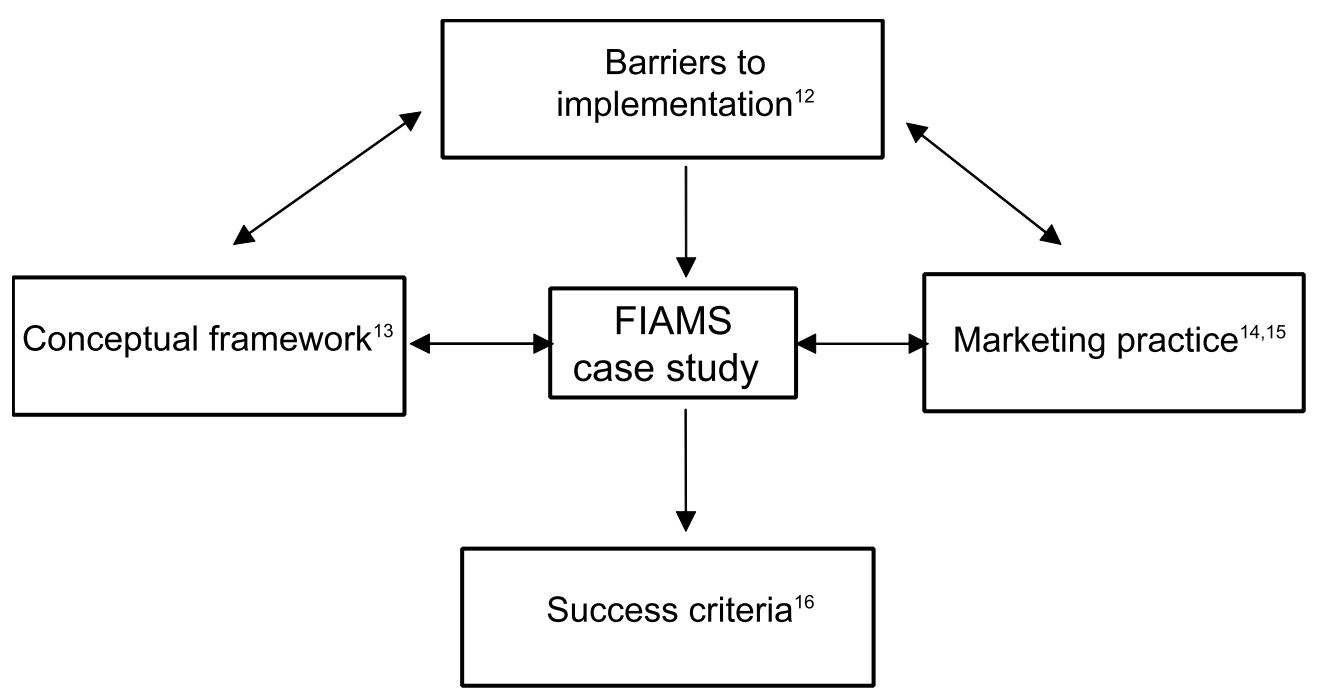

Figure 1: IT adoption and marketing practice

Table 1: Marketing and IT - Development phases

\begin{tabular}{|c|c|c|c|c|}
\hline & Phase 1 & Phase 2 & Phase 3 & Phase 4 \\
\hline Characterisation & 'Mystery lists' & 'Buyer databases' & $\begin{array}{l}\text { 'Co-ordinated } \\
\text { customer } \\
\text { communications' }\end{array}$ & $\begin{array}{l}\text { 'Customer } \\
\text { relationship } \\
\text { management' }\end{array}$ \\
\hline \multirow[t]{2}{*}{ Application } & Direct mail & $\begin{array}{l}\text { Direct mail } \\
\text { Telemarketing } \\
\text { Sales support }\end{array}$ & $\begin{array}{l}\text { Planning and } \\
\text { resource allocation } \\
\text { tool }\end{array}$ & $\begin{array}{l}\text { Fully integrated tool } \\
\text { for strategic and } \\
\text { tactical planning }\end{array}$ \\
\hline & & & $\begin{array}{l}\text { Integrated } \\
\text { communication }\end{array}$ & \\
\hline
\end{tabular}

increasingly strategic to marketing practice. Their original framework is adapted and summarised in Table 1. This would suggest that the first phase is primarily used for direct mail and as a first step to gaining experience in the application of IT for marketing purposes. Although the framework was developed before the introduction of the Internet and associated opportunities for e-business, this original framework stands comparison with the positioning of database marketing in Phase 1 and customer relationship management in Phase 4. Shaw and Stone also go on to present guidelines for implementation and management practice. These guidelines in turn assist companies to move between the various phases that they propose.

The work of the CMP group shows that a range of different styles of marketing can be identified. ${ }^{18}$ It has been proposed that there has been a paradigm shift from transactional to relational marketing. ${ }^{19}$ More pragmatically, the empirical work of the CMP group suggests that while a particular style of marketing may be dominant within a sector a complete transition or shift appears unlikely. In particular, the relational style of marketing is associated with business-to-business firms. ${ }^{20}$ The results of this study also confirm, however, that while a particular type of firm may have a predominant style of 


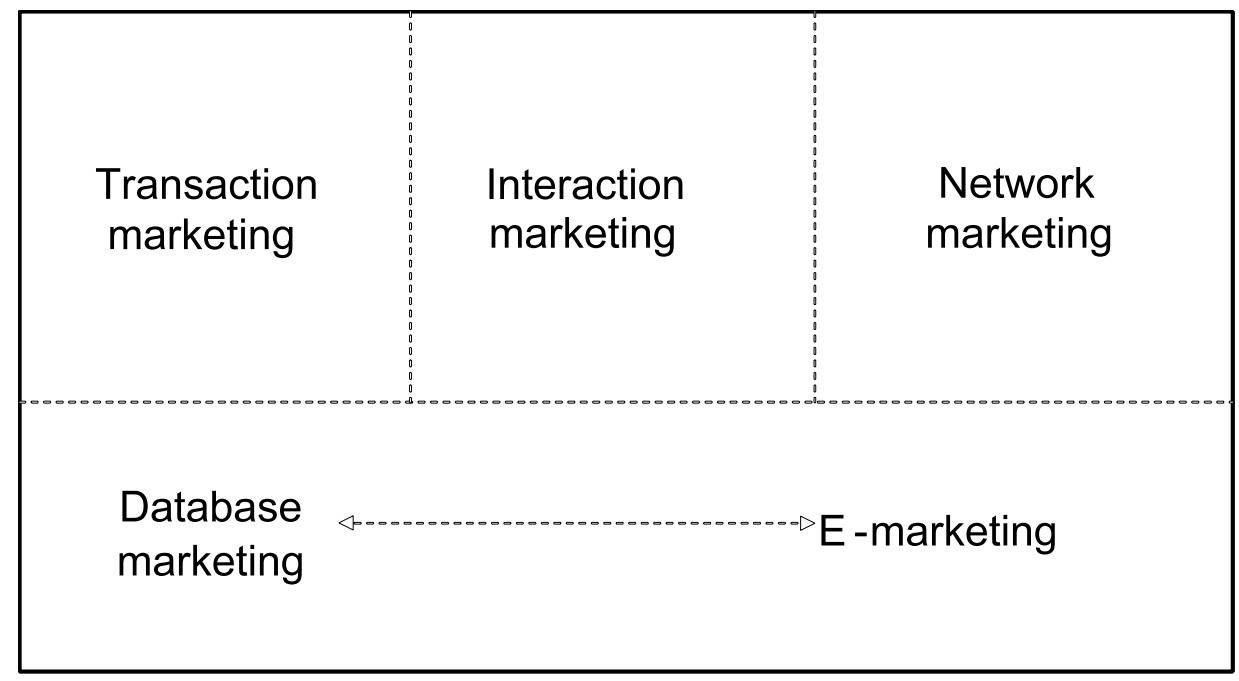

Figure 2: $\quad$ Marketing practice and IT

marketing, in practice it is likely that most firms will demonstrate a range of styles.

This adds to the complexity of the management task and the importance of guidelines for best and most effective practice. In attempting to manage a suite of marketing practices, however, the CMP group proposes that IT has an underpinning and trans-practice role (Figure 2). This is consistent with the conceptual model originally proposed by Shaw and Stone.

Fletcher and Wright ${ }^{21}$ and Desai et al. ${ }^{22}$ have considered the barriers to the successful implementation of IT in the financial services, retail and travel sectors. This is of particular interest as they have considered this in terms of a specific IT application, with respect to database marketing. This is analogous to Phase 1 of the framework outlined by Shaw and Stone. The following lists, in rank order, the barriers to database marketing adoption that they have identified in their work:

— high cost of development

- highly fragmented systems
- data quality

- account-based customer records

- no clear database marketing strategy

- lack of company-wide marketing orientation

— lack of direct marketing specialists

- fragmented sales and marketing organisation

— lack of board-level backing

- agency relations

- poor relationships between marketing and IT.

The review of the literature here gives a framework in which IT implementation can be understood and a series of empirically-derived guidelines for understanding the process of marketing practice and IT implementation can be derived. The use of IT applications for marketing purposes represents an innovation in managerial practice. The Shaw and Stone framework suggests that such innovation becomes more strategic as implementation progresses. This implies an increase in risk, in anticipation of improved returns. Innovation, particularly with IT and technology-based tools, is, however, inevitably inherently risky. ${ }^{23}$ 
In the case study discussed below the managers concerned regarded their innovation in terms of new product development. By experimenting with direct marketing techniques they acted first to reduce the risks associated with innovation and a full-scale commitment to an unfamiliar style of marketing.

Secondly, they were able to generate data to justify further investment and commitment at a strategic level within the firm. Poolton and Barclay ${ }^{24}$ review the product development literature and discuss a series of criteria important to new product success, six of which they describe as strategic. They comment that despite the extensive work in the field the various factors associated with success have not been satisfactorily extended further into managerial practice. The context of the case study provides an opportunity to use these criteria to evaluate the success of the 'product'. The new product development and innovation success factors they identify are:

— top management support for innovation

- long-term strategy with an innovation focus

- long-term commitment to major projects

- flexibility and responsiveness to change

- top management acceptance of risk

- support for an entrepreneurial culture

- lack of direct marketing specialists

- fragmented sales and marketing organisation.

The success criteria are used to evaluate the overall success of the project at the conclusion of the case study. In reality, however, the managers concerned regarded their efforts as a continual stream of activity rather than a series of discrete projects.

\section{METHODOLOGY}

The selection of the case study as a research methodology and the techniques of the research were in accordance with the principles outlined by Yin. ${ }^{25}$ The case study method was chosen for a number of reasons. First, the importance of context. As the analytical criteria were developed within other industries, this case gave the opportunity to consider a business-to-business goods company. Secondly, the subject case represented a unique opportunity to obtain access to data that would otherwise not be obtainable. Finally, the case was regarded as exploratory as it tests a number of concepts within the context of the case.

Data were collected using a number of methods. Key managers within the company were interviewed both formally and informally over a period of time. In addition, company records and reports were made available together with detailed financial and other data relating to the subject of the study. The unit of analysis is the promotional programme which provides the boundaries to the case. As is usual with the case study methodology, the data that are gathered are limited by the boundaries of the study and access to and availability of information. In addition the boundaries to the case limit the extent of the research. In practice, the activity reported was part of a continual stream of activity within the company rather than an isolated promotional programme.

\section{THE CASE: FOOD INGREDIENTS AND MENU SUPPLIES LTD (FIAMS)}

\section{Introduction}

The company, Food Ingredients and Menu Supplies Ltd (FIAMS), ${ }^{26}$ provides a full range of food ingredients, menu components and ready-cooked meals for public houses, restaurants and institutions 
such as schools and hospitals. The company has a full product range and can supply anything from a packet of spices and prepared vegetables to a full menu range which only needs to be heated prior to being served. In order to maintain a high level of service and product quality the company has a number of commercial kitchens around the country and its own dedicated, refrigerated transport fleet. The company also employs a large field force who call regularly on their customers in order to take orders, sell new product lines and provide technical support and training in areas such as kitchen layout and design, equipment selection and training in food hygiene and handling.

The company has grown steadily over the years from its family roots and while never enjoying spectacular success has achieved its position as an industry major by never making a mistake either. The company is traditional and risk averse, but not dynamic or innovative.

With increasing levels of disposable income consumers have been more inclined to spend money on meals out of the home. As a consequence this requires continual innovation and new meal experiences to maintain their interest. It is noticeable that the marketplace is becoming increasingly segmented and more competitive. FIAMS have found that their traditional selling methods, using a field sales force, and conservative approach to innovation has meant that increasing costs are not being recovered by either new account gains or maintained and improved margins. This has meant that they must now address these issues before profitability declines further.

\section{The marketing team}

FIAMS had recognised that they were losing position in the market and several years previously had recruited a new marketing manager. This had resulted in a reorganisation of the marketing effort with product managers being appointed for each market segment. It was now apparent, however, that despite the improved marketing effort, particularly in the area of product development, the company was not satisfactorily developing its market share.

The marketing team decided to implement an account gain strategy and in particular wanted to focus on clients with whom they had not previously traded. The information system that the company used was largely product-line driven and it was difficult to obtain information in sufficient detail for marketing purposes. After some consideration it was decided that the company would cease advertising in various trade journals and instead reinvest the money in a database marketing campaign. The company had been advertising on a monthly basis in various journals, sometimes for as long as 22 years continuously. The marketing manager considered that the advertisements were of marginal value and this represented a source of funds that could usefully be reinvested elsewhere.

\section{Database marketing}

Apart from the advertising budget and their vision and enthusiasm, the marketing team had little by way of resources to call on. At an early stage it was decided to outsource much of the work to external agencies, and in addition to keep detailed records in order to track the effectiveness of the programme. This was known within the company as the 'black box' approach, as so much reliance was placed upon agency partners in terms of both their expertise and resources. 
Several agencies were approached with a brief as to the requirements, and one was selected as the primary agency partner. The agency provided the creative ideas for the promotion together with merchandise and administrative capability. As the target market was new customers it was decided to buy-in lists of potentially suitable clients from external agencies and list providers.

As the campaign progressed various techniques were experimented with, sometimes on a regional basis for purposes of comparison, in order to gain further insight. One such technique was the use of an external outbound call centre in order to follow up mailshots and increase response rate.

\section{Organisation}

The company was organised into four trading regions, with a central head office which include the marketing department. Within the marketing department one manager was given prime responsibility for agency liaison, the regions were strongly discouraged from contacting the agencies directly in order to avoid confusion. Within each trading region a manager was appointed to act as the regional campaign manager (RCM). A series of meetings were held around the regions, in order to ensure that all the relevant staff were briefed before the campaign began. These were conducted in two stages, first with the RCMs. In these meetings an agreed and standardised process was developed for the physical handling of customer responses and the subsequent fulfilment and sales calls. The second round of meetings was a briefing to sales staff on the detail of the campaign. The senior regional management team were involved throughout.

\section{Direct mail campaign}

Initial market research among the target customer base identified an opportunity for a value-based market proposition. The research showed that the market was receptive to a message that showed how FIAMS products could support clients' opportunities to improve customer appeal and revenue generation.

The results of this initial market research were incorporated into a brief which was circulated to three agencies, from which one was selected. FIAMS worked closely with the agency to develop appropriately themed promotional literature for direct mailing and also for use by the sales force.

The mailshots themselves were conducted in two phases. First a value-led proposition enhancing and supporting the main theme of the campaign. Non-respondents then received a second mailshot a few weeks later which emphasised the gift available to respondents in order to encourage their feedback. The purpose of the mailshots was to generate response which could be followed up by the salesperson. The tool to achieve this was the respondent gift. The agency suggested an antique map of the county in which the business was situated which was discreetly overprinted with the company logo. As an extra incentive the map would be supplied framed and ready for hanging to all those who purchased FIAMS products. The map was chosen due to its high perceived value, low unit cost and appeal to the customer. In various areas a follow-up telephone campaign was put in place to test the effectiveness of gaining additional responses using this method.

Critical to the campaign was the quality of the lists of potential customers. These were purchased from a number of sources, such as trade publications and specialist list providers. The list providers 
Table 2: Campaign output and response trading regions

\begin{tabular}{lrrrrr} 
& A & B & C & D & Total/Average \\
\hline First mailing: & & & & & \\
Number of pieces dispatched & 5,299 & 8,942 & 3,465 & 601 & 18,307 \\
Response & 260 & 523 & 189 & 37 & 1,009 \\
\% response & 4.9 & 5.8 & 5.5 & 5.6 & 5.5 \\
Second mailing: & & & & & \\
Number of pieces dispatched & 1,518 & 3,252 & 1,100 & - & 5,870 \\
Response & 62 & 159 & 43 & - & 264 \\
\% response & 4.1 & 4.9 & 3.9 & - & 4.5 \\
New accounts & 43 & 50 & 11 & 2 & 106 \\
\% conversion & 13.3 & 7.3 & 4.7 & 5.4 & 8.3 \\
Gross profit £ (3 months) & 52,462 & 43,705 & 8,370 & 1,587 & 106,124 \\
& & & & & \\
Telephone follow-up calls & 598 & 472 & 317 & - & 1,387 \\
Number allocated & 552 & 209 & 221 & - & 982 \\
Contact made & 213 & 108 & 21 & - & 342 \\
Appointments & 39 & 57 & 9.5 & - & 35 \\
\% success & & & & & \\
\hline
\end{tabular}

also undertook to cross-check FIAMS' customer list against their own lists in order that, as far as possible, only genuine prospects were contacted.

Response to the campaign was via a reply-paid card which also sought to capture additional useful information. Each RCM was responsible for administering the reply-paid cards and managing them through the process flow system previously devised. As the company was adopting a black box approach this was essentially paper-based and although labour intensive proved to be reliable. A default system was also put in place so that if a respondent was not contacted within 28 days then a covering letter and promotional map were automatically dispatched.

Each salesperson was provided with a framed map together with the response cards appropriate to their area and was then tasked with visiting the leads generated as soon as possible. The dispatch of maps both framed and unframed, was incorporated into the flow process. The unframed maps were delivered by the salesperson in order to initiate the personal relationship from a positive basis.
As an experiment, in order to gather more data for analysis, it was decided during the course of the campaign to utilise an outbound call centre to contact clients who had not responded to the second direct mail piece. The objective of these calls was to gain an appointment for a sales representative to visit. Areas within each trading region were selected and a number of non-respondents identified.

\section{Results}

Summary results from the campaign are noted in Table 2.

The focus of the campaign was new customer gain which in turn required a definition of a new customer, ie a customer who had not traded with the company in the previous 12 months. The management information system enabled customers gained as a result of the campaign to be identified and their purchases tracked.

All costs associated with the campaign were carefully recorded, this was made easier by the fact that the company adopted the black box approach from the outset. This made it easier to identify 
and cost the resources that were specifically allocated to this activity. The total cost of the campaign was $£ 82,721$; this can be compared to the average expenditure on advertising of approximately $£ 100,000$. After three months following the campaign the contribution or gross profit attributable to new customers was $\mathcal{f} 106,126$. For the nine-month period following the campaign this increased to $\mathcal{E}^{269,714 \text {. }}$

In addition, there were non-financial benefits identified by the company which included a substantial bank of qualified new contacts, approximately 1,000 , that had been identified by the campaign but had yet to purchase. Valuable insight was gained with regard to the costs, benefits and process of running such a campaign together with a new customer orientation that was ignited within the salesforce. The quantitative data obtained by the sales region also enabled detailed analysis of the conversion rates of prospects to customers, both by sales teams and individual salespeople. The highest rate of conversion was 13.5 per cent, but one sales team and a number of individual salespeople were unable to gain any additional sales.

\section{Discussion}

Of particular interest with this case study is the detailed nature of the records that have been kept. These demonstrate an acceptably high response rate to both the first and second mailing; the company had aimed for a 2.5 per cent response rate and were therefore very happy to achieve a response of double this. The conversion of responses to accounts at less than 1 per cent suggested, however, ample opportunity for improvement.

The first mailshot focused on a targeted message based on previous market research and identified customer needs, with the overall theme of quality and value for money. The second mailshot was a more aggressive premium-led offer, emphasising the free gift that was available when replying. In the follow-up discussions between the company and their various agencies the reasons for the good response rate were discussed. These were identified as:

- good sales prospect selection

- a targeted message

— interesting and engaging premium offered

- a low level of experience/exhaustion among the customer base of this type of campaign.

Response was further enhanced by the selective use of an outbound call centre that telephoned non-respondents. This showed a substantial increase in appointments, which significantly exceeded expectations. The perception of the sales management team was, however, that these leads were generally of lower quality, perhaps associated with the ease with which commitment can be obtained by a persuasive telephone call.

The detailed and quantified approach to the management of the campaign also gave considerable insight into salesforce efficiency and effectiveness. While many members of the sales team were enthusiastic about the opportunities that this provided them with to increase their own sales and consequent commissions, it was also noted that other members of the sales team exhibited some discomfort with the degree of disclosure that this revealed. This led to some further interesting conclusions with respect to sales management, as discussed below.

Customer knowledge: it was assumed within the company that established salespeople had an intimate knowledge of their trading area and the key customers within it. The analysis showed that this level of understanding was significantly 
lower than was thought, even with very experienced and successful salespeople. This could be due to a number of factors, 'milkrounding' where less effective salespeople are content to over-service current customers. Alternatively, the most effective salespeople have reached capacity in what they are able to achieve, with the further implication that better sales management or additional sales resource could give extra return.

Salesforce attitude: the allocation of sales leads down to the level of individuals who were then monitored with respect to the number of calls they made and the sales achieved led to the evident discomfort of some salespeople. The campaign demonstrated that some members of the salesforce actually felt uncomfortable and uncertain in dealing with entirely new potential customers, while others revelled in the opportunity to gain sales volume. Sales managers found that a number of reasons for not calling on prospective customers were regularly used. These included lack of time, the bad debt risk thought to be associated with the customer, previous disappointment and poor trading history at some time in the past or exceptional levels of loyalty to the current supplier.

Sales management: the quantification of the campaign emphasised not only accountability on behalf of salespeople but also of sales management. There had been substantial and detailed briefings, and development of the campaign was conducted in conjunction with the sales managers. This high level of internal communication and consequent positive attitude and commitment was considered essential to the success of the campaign. The experience gained emphasised the importance of organisation on behalf of the sales managers and the importance of sales training and the clear definition of objectives for salespeople.

As part of the campaign development a process had been devised in order to capture and track responses from customers. RCMs had been appointed in each region to administer the campaign and as part of the debriefing and learning from the experiment they were asked for their feedback.

'On the administration side, the response traffic form proved to be a very good tracking record, enabling the RCM to monitor progress.'

'As an RCM I found that the administration was well thought out and I had no difficulties in coping with the mass of cards received on a daily basis.'

The time invested in consulting regional staff and developing a process, supported by forms such as the response traffic form referred to above, was generally thought to have worked well. As this was the first time that the company had undertaken such an activity the process was largely paper-based and manually operated. This led to the major disadvantage in that it was time consuming and occasionally cumbersome.

'We did find it time-consuming but feel this was necessary in order to adequately track all requests.'

'The follow-up proved more difficult than first thought, particularly achieving the required timescale to enable replies to be returned to the direct mail house within the time required.'

'The only problem seems to be receiving the framed maps. This has taken such a long time that it has lost a bit of impact and it may have put at risk subsequent orders.'

These disadvantages can be readily overcome with the wider use of e-mail and PC-based tools. 
Table 3: Barriers to database marketing adoption - Comparison with case data

\begin{tabular}{|c|c|c|}
\hline Barrier & Case data & Rating \\
\hline High cost of development & $\begin{array}{l}\text { Development costs limited by treating costs as variable. } \\
\text { Minimal investment in systems with paper-based } \\
\text { administration being used }\end{array}$ & 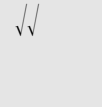 \\
\hline $\begin{array}{l}\text { Highly fragmented } \\
\text { systems }\end{array}$ & $\begin{array}{l}\text { FIAMS has a range of IT systems but used a standalone } \\
\text { database to manage the campaign. Once new customers } \\
\text { were gained then data were entered into the company } \\
\text { system }\end{array}$ & $\mathrm{X}$ \\
\hline Data quality & $\begin{array}{l}\text { Quality of bought-in lists was considered reasonable, } \\
\text { augmented by additional response data. However in-house } \\
\text { systems inadequate for database marketing purposes }\end{array}$ & $\mathrm{X}$ \\
\hline $\begin{array}{l}\text { Account-based customer } \\
\text { records }\end{array}$ & A problem once new customers were recruited & $x$ \\
\hline $\begin{array}{l}\text { No clear database } \\
\text { marketing strategy }\end{array}$ & $\begin{array}{l}\text { The campaign was used as a means to understand how to } \\
\text { develop and benefit from a strategy }\end{array}$ & 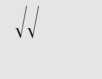 \\
\hline $\begin{array}{l}\text { Lack of company-wide } \\
\text { marketing orientation }\end{array}$ & $\begin{array}{l}\text { Intensive and regular communication generated commitment } \\
\text { to the campaign and success to market the 'product' further }\end{array}$ & $\sqrt{ }$ \\
\hline $\begin{array}{l}\text { Lack of direct marketing } \\
\text { specialists }\end{array}$ & $\begin{array}{l}\text { Addressed by the 'black box' strategy of buying-in } \\
\text { appropriate skills, developing processes and measuring } \\
\text { results in order to gain insight }\end{array}$ & W \\
\hline $\begin{array}{l}\text { Fragmented sales and } \\
\text { marketing organisation }\end{array}$ & $\begin{array}{l}\text { Processes used to draw in and coordinate resources, } \\
\text { departments and regions }\end{array}$ & $\sqrt{ }$ \\
\hline $\begin{array}{l}\text { Lack of board-level } \\
\text { backing }\end{array}$ & Sponsored by the marketing director & $\sqrt{ }$ \\
\hline Agency relations & $\begin{array}{l}\text { Careful agency selection to ensure good professional skills } \\
\text { and appropriate cultural fit }\end{array}$ & ل \\
\hline $\begin{array}{l}\text { Poor relationships between } \\
\text { marketing and IT }\end{array}$ & IT department not involved at this stage & $X X$ \\
\hline
\end{tabular}

Barrier overcome: Not at all ------------------- To a great extent

$\mathrm{XX} \quad \mathrm{X}-\sqrt{ }$

\section{CONCLUSIONS}

In using the Shaw and Stone framework it can be understood that the company was in Phase 1 with respect to this campaign, characterised by the CMP group as database marketing.

The literature review identified the barriers to successful implementation. It is interesting by way of conclusion to compare the case study findings against these criteria (Table 3).

Against the list of criteria in Table 3 it can be seen that FIAMS was able to develop coping strategies in order to enable experimentation with the technique. This analysis shows, however, that issues related to IT were dealt with only at the tactical level, sufficient to enable the campaign. For further progress a more strategic approach to IT and its use for marketing purposes must be developed.

The marketing team responsible for the campaign always regarded it as an experiment in order to prove or disprove the technique. Detailed record keeping and post-campaign debriefing enabled them to assess fully the benefits or otherwise resulting from the campaign. Had it been unsuccessful, then the campaign could have been reviewed in order that the process could be 
Table 4: Strategic success factors - Comparison to case data

\begin{tabular}{|c|c|c|}
\hline Criterion & Case data & Rating \\
\hline $\begin{array}{l}\text { Top management support } \\
\text { for innovation }\end{array}$ & $\begin{array}{l}\text { Marketing director as sponsor, using funds already allocated. } \\
\text { Gaining further data in order to manage risk and exposure } \\
\text { and gain further support }\end{array}$ & $\checkmark$ \\
\hline $\begin{array}{l}\text { Long-term strategy with an } \\
\text { innovation focus }\end{array}$ & $\begin{array}{l}\text { A clear strategy to address sales costs, margin decline and } \\
\text { need for growth }\end{array}$ & $\sqrt{ }$ \\
\hline $\begin{array}{l}\text { Long-term commitment } \\
\text { to major projects }\end{array}$ & $\begin{array}{l}\text { A long-term vision, but a potentially major project divided } \\
\text { into smaller, more manageable elements to match } \\
\text { capabilities, risk and need for investment }\end{array}$ & - \\
\hline $\begin{array}{l}\text { Flexibility and } \\
\text { responsiveness to change }\end{array}$ & $\begin{array}{l}\text { Relatively low need due to limited nature of the campaign } \\
\text { and good process development }\end{array}$ & $x$ \\
\hline $\begin{array}{l}\text { Top management } \\
\text { acceptance of risk }\end{array}$ & $\begin{array}{l}\text { Management prepared to experiment but must manage } \\
\text { exposure against risk }\end{array}$ & $\checkmark$ \\
\hline $\begin{array}{l}\text { Support for an } \\
\text { entrepreneurial culture }\end{array}$ & An open-minded approach to new ideas & - \\
\hline
\end{tabular}

improved. Had performance been very poor the technique could have been dismissed.

The marketing team regarded the campaign as successful and the data generated as tools for justifying further development. In this sense, it was a 'product' being developed by the marketing team to 'sell' to the board in order to gain further commitment and investment. The success of this product development process can be considered within the context of the case against the criteria of Poolton and Barclay (Table 4).

These conclusions would suggest that while the company is conservative and risk averse, provided that risk and exposure can be managed then there is the opportunity to develop new ideas. This is within the context of a company suffering declining margins, increasing costs and poor growth. It could be speculated that a traditional and risk-averse organisation such as FIAMS would be less likely to experiment with new techniques if commercial performance was considered to be satisfactory. While FIAMS may have failed to benefit from full and early application of innovative techniques the incremental approach adopted served to reduce and manage risk.

The use of the case study technique has helped to draw together a number of conceptual and empirical frameworks. A single case study, while exploratory, does demonstrate the validity of the Shaw and Stone conceptual framework supported by the CMP empirical work. The barriers to database implementation proposed by Desai et al. and developed in other industries, have helped to give worthwhile insight and understanding in a different context. Poolton and Barclay in their original paper discuss the problems involved in translating generalised research into specific cases and contexts. Their framework for the success of new products was less worthwhile within the boundaries of the case study, particularly as FIAMS is risk averse and is not necessarily visionary and forward looking.

Following the success of this initial 
experiment the company went on to develop two further campaigns in specific niche markets. One focused on a particular segment of the marketplace in which the company was known to be under-represented, the other to a high-value but relatively low-volume market segment. In particular, the company sought to improve interest generation and sales conversion rates by better targeting, more engaging promotions and higher-quality sales management and technique.

The knowledge and experience gained through these campaigns and the commercial success enjoyed led to the next stage of strategic development. In particular, the board agreed to a substantial capital investment in a relational database IT system intended to provide much more useful and actionable data for marketing purposes. FIAMS therefore progressed to the next stages of development illustrated by the conceptual and empirical frameworks.

\section{References}

1 Christensen, C. M. (1997) 'Innovators dilemma: Why great companies fail', Harper Collins, New York.

2 Brodie, R. J., Coviello, N. E., Brookes, R. W. and Little, V. (1997) 'Towards a paradigm shift in marketing? An examination of current marketing practices', Journal of Marketing Management, Vol. 13, pp. 383-406.

3 Coviello, N. E., Brodie, R. J., Brookes, R. W. and Palmer, R. A. (2001) 'The role of e-marketing in contemporary marketing practice', Proceedings of the 9th International Colloquium in Relationship Marketing, John Molson School of Business, Concordia University, Montreal, September.

4 Shaw, R. and Stone, M. (1988) 'Database marketing', Gower, Aldershot.

5 Poolton, J. and Barclay, I. (1998) 'New product development from past research to future applications', Industrial Marketing Management, Vol. 27, pp. 197-212.

6 CIM (2002) 'The impact of e-business on marketing and marketers', www.cim.co.uk.

7 Shaw and Stone (1988) op. cit.

8 Desai, C., Wright, G. and Fletcher, K. (1998) 'Barriers to successful implementation of database marketing: A cross industry study', International Journal of Information Management, Vol. 18, No. 4, pp. 265-276.

9 Poolton and Barclay (1998) op. cit.

10 Yin, R. K. (1994) 'Case study research - Design and methods', Sage, London.

11 Fletcher, K. and Wright, G. (1995)

'Organizational, strategic and technical barriers to successful implementation of database marketing', International Journal of Information Management, Vol. 15, No. 2, pp. 115-126.

12 Desai et al. (1998) op. cit.

13 Shaw and Stone (1988) op. cit.

14 Brodie et al. (1997) op. cit.

15 Coviello et al. (2001). op. cit.

16 Poolton and Barclay (1988) op. cit.

17 Shaw and Stone (1988) op. cit.

18 Brodie et al. (1997) op. cit.

19 Kotler, P. (1991) 'Philip Kotler explores the new marketing paradigm', Marketing Sciences Institute Review, Spring

20 Coviello et al. (2001) op. cit

21 Fletcher and Wright (1995) op. cit.

22 Desai et al. (1998) op. cit.

23 Christensen (1997) op. cit.

24 Poolton and Barclay (1998) op. cit.

25 Yin (1994) op. cit.

26 For commercial reasons the name of the company and certain company details have been disguised. 
